\title{
ANALISIS GERAK MOTORIK DASAR SISWA KELAS VII SMP NEGERI 1 KECAMATAN KUOK KABUPATEN KAMPAR
}

\author{
Rezki \\ Universitas Islam Riau \\ Rezki433@gmail.com
}

\begin{abstract}
ABSTRAK
Gerak fundamental ditentukan berdasarkan kemampuan seseorang menguasai tiga kelompok dasar gerak yaitu Non-Lokomotor, lokomotor, dan manipulatif.Tujuan penelitian ini adalah untuk mengetahui analisis kesesuaian gerak dasar siswa dengan tingkat usianya. Metode yang digunakan penelitian ini adalah metode deskribtif. Subjek penelitian ini adalah siswa kelas VII SMP Negeri 1 Kuok berjumlah 114 siswa.Siswa diminta melakukan 22 gerak yang masuk dalam kelompok gerak Non-Lokomotor, lokomotor, dan manipulatif. Gerak siswa direkam menggunakan kamera, dan hasil rekaman dianalisis menggunakan pedoman observasi kemudian dianalisis dari persentase nilai gerakan yang dilakukan.Hasil penelitian ini menemukan bahwa nilai kesesuaian gerak siswa putra lebih baik dibanding dengan siswa putri. Ketiga jenis kelompok gerak dasar dijelaskan bahwa kelompok gerak Non-Lokomotor masuk dalam kategori cukup $(74,5 \%)$, lokomotor masuk dalam kategori cukup $(77,4 \%)$, dan manipulatif masuk dalam kategori baik $(85,25 \%)$. Dari hasil analisis tiga jenis kelompok gerak dasar tersebut dapat diketahui kesesuaian gerak dasar masuk dalam kategori baik (79\%).
\end{abstract}

Kata kunci: Non-Lokomotor, Lokomotor dan Manipulatif

\section{PENDAHULUAN}

Setiap anak menggunakan seluruh waktunya untuk bergerak, yaitu gerakan kasar yang menggunakan sebagian besar tubuhnya, seperti berlari, melompat, dan melempar.Ia juga melakukan gerakan tubuh yang bersifat keterampilan terbatas, seperti menggunting, menempel, dan mendorong. Gerak fundamental ditentukan berdasarkan kemampuan seseorang menguasai tiga kelompok dasar gerak yaitu Non-lokomotor, lokomotor, dan manipulatif.

Gallahue (1996:262-331) mengatakan Pola gerak dasar adalah bentuk gerakangerakan sederhana yang bisa dibagi kedalam tiga bentuk gerak sebagai berikut:

1. Gerak lokomotor (gerakan berpindah tempat) dimana bagian tubuh tertentu bergerak atau berpindah tempat; misalnya jalan,lari,dan loncat.

2. Gerak Non-Lokomotor (gerakan tidak berpidah tempat) dimana sebagian anggota tubuh tertentu saja yang digerakkan namun tidak berpindah tempat.

3. Manipulatif, dimana ada sesuatu yang digerakkan, misalnya melempar, menangkap, menyepak, memukul, dan geraka lain yang berkaitan dengan lemparkan dan tangkapan sesuatu.

Kemampuan motorik akan berkembang menjadi suatu keterampilan motorik tertentu. Hal itu akan tergantung sejauh mana mereka mendapat pengalaman- 
pengalaman gerak dari lingkungan sekitarnya. Perkembangan motorik kasar anak berkaitan dengan kemampuan menggunakan gerak seluruh tubuh untuk mengekspresikan ide dan perasaannya serta ketrampilan menggunakan tangan untuk menciptakan atau mengubah sesuatu. Perkembangan motorik kasar ini meliputi kemampuan fisik yang spesifik seperti koordinasi, keseimbangan, ketrampilan, kekuatan, kelenturan, kecepatan dan keakuatan untuk menerima rangsangan, sentuhan dan tekstur. Keterampilan motorik kasar anak sangat penting, sebab motorik kasar anak yang rendah akan menimbulkan masalah perilaku dan emosi bagi anak.

Sumantri (2005:187) Ciri-ciri keterampilan motorik kasar yang rendah, antara lain:

1. Kurang aktif dalam mengikuti pembelajaran motorik (pendiam). Anak terlihat tidak aktif, tampak selalu diam sekalipun kondisi sedang sehat, didalam kelas pada saat mengerjakan tugas selalu diam jarang bergerak.

2. Kurang percaya diri, karena ketidak mampuan dalam melakukan berbagai kegiatan fisik/motorik yang diberikan.

3. Malas dan tidak mau berusaha, anak yang memiliki perkembangan motorik yang sangat rendah dalam setiap kegiatan yang membutuhkan tenaga tidak pernah mau melaksanakan.

4. Kurang mandiri karena ketidak mampuan melakukan semua aktivitas sendiri, maka setiap kegiatan atau pekerjaan selalu meminta bantuan orang lain.

Lembaga pendidikan anak usia dini yang seharusnya menjadi fasilitas bagi perkembangan motorik kasar, ternyata masih banyak guru yang masih hanya mengandalkan pembelajaran membaca, menulis dan berhitung, sehingga perkembangan keterampilan motorik kasar anak seringkali terabaikan. Seiring dengan pertambahan usia dan dipengaruhi oleh faktor latihan, gerakan-gerakan tersebut akan menjadi semakin sempurna.

Jean Piaget berpendapat bahwa pemikiran kanak-kanak berbeda pada masingmasing tingkatan. Ia membagi perkembangan pemikiran kanak-kanak menjadi empat tingkatan; tingkatan sensorimotor, tingkat praopersai, tingkatan operasi konkret, dan tingkatan operasi formal. Setiap tahap mempunyai tugas kognitif yang harus diselesaikan. Tingkatan sensori motor ( $0-2$ tahun), pemikiran anak berdasarkan tindakan indrawinya.Tingkatan Praoperasional (2-7 tahun), pemikiran anak ditandai dengan penggunaan Bahasa serta tanda untuk menggambarkan konsep.Tingkatan Operasi konkret (7-11 tahun) ditandai dengan penggunaan aturan aturan logis yang jelas. Tahap Operasi Formal dicirikan dengan pemikiran abstrak, hipotesis, deduktif, serta induktif.

Keterampilan motorik kasar yang lebih maju dari sekadar refleks merupakan prasyarat untuk berolahraga, menari, dan aktivitas-aktivitas lain pada masa usia sekolah dasar dan tahap perkembangan selanjutnya.

Pada tingkat sekolah menengah pertama seharusnya siswa sudah mahir dalam melakukan keterampilan motorik kasar tesebut, karena pada usia 11-14 tahun mereka sudah mulai melakukan variasi keterampilan teknik yang benar untuk persiapan yang lebih berat. Akan tetapi yang kondisi nyata sekarang ini masih banyak siswa SMP Negeri 1 Kuok belum terampil dalam melakukan gerak dasar seperti berlari, melempar, memukul dan gerakan dasar lainnya yang sesuai dengan tingkat usianya. Oleh sebab itu peneliti tertarik untuk mengkaji lebih dalam permasalahn yang terjadi pada siswa SMP Negeri 1 Kuok tersebut. Peneliti merumuskan pertanyaan penelitian yakni: 
1. Bagaimanakah kemampuan gerak dasar locomotor siswa SMP Negeri 1 Kuok?

2. Bagaimanakah kemampuan gerak dasar non-lokomotor siswa SMP Negeri 1 Kuok?

3. Bagaimanakah kemampuan gerak dasar manipulative siswa SMP Negeri 1 Kuok?

\section{METODE PENELITIAN}

Metode yang digunakan dalam penelitian ini adalah metode deskriptif.Tujuan dari penelitian deskriptif adalah untuk membuat deskriptif, gambaran atau lukisan secara sistematis, faktual dan akurat mengenai fakta-fakta, sifat-sifat serta hubungan antara fenomena yang diselidiki (Nazir, 1988:63). Subjek dari penelitian ini adalah Siswa SMP Negeri 1 Kuok Kelas VII yang berjumlah 114 orang yang terdiri dari 65 laki-laki dan 49 perempuan. Teknik pengambilan sampel dalam penelitian ini mengunakan total sampling. Istrumen penelitian ini adalah dengan melakukan pengamatan lansung dengan cara menvideokan siswa sewaktu melakukan gerakan, kemudian videonya di analisis tim peneliti sesuai dengan kriteria penilaian gerak disesuaikan denga tingkatan umur anak E-elementary stages sama dengan SMP Kelas 7 (Gallahue, 1996:262-331). Dari keterangan hasil Observasi sesuai dengan instrumen pegambilan data, dapat dijelaskan dan dimodifikasi untuk menjadi pedoman Observasi yang dilengkapi dengan skala penilaian sebagai berikut:

1. Nilai 1 untuk kualitas gerak Kurang.

2. Nilai 2 untuk kualitas gerak Cukup.

3. Nilai 3 untuk kualitas gerak Baik.

Sehingga dari nilai tersebut dapat dihitung nilai kesesuaian gerak menjadi persentase menggunakan rumus proporsi sebagai berikut:

$$
\text { kesesuaian gerak }(\%)=\frac{\sum \text { nilai }}{\text { nilai maksimal }} \times 100 \%
$$

Dari hasil hitung di atas akan didapat nilai berupa persen. Nilai persen tersebut selanjutnya diinterpretasikan menjadi tiga kategori yaitu: (1) kategori kurang; (2) kategori cukup dan (3) baik.

\section{HASIL DAN PEMBAHASAN}

\section{Non-Lokomotor}

Dari 22 tes gerak dasar, yang termasuk dalam kelompok gerak non-lokomotor adalah Static balance, dynamic balance, body rolling, dan dodging. Hasil analisis gerak dasar Non-Lokomotor sebagai berikut:

Tabel 1. Nilai Kesesuaian Gerak Non-Lokomotor

\begin{tabular}{|c|c|c|}
\hline Gerak Dasar & & Rerata \\
\hline \multirow{2}{*}{ 1. Static balance } & Nilai & $62 \%$ \\
\hline & Kategori & $\mathrm{C}$ \\
\hline \multirow{2}{*}{ 2. Dynamic balance } & Nilai & $86 \%$ \\
\hline & Kategori & $\mathrm{B}$ \\
\hline \multirow{2}{*}{ 3. Body rolling } & Nilai & $72 \%$ \\
\hline & Kategori & $\mathrm{C}$ \\
\hline 4. Dodging & Nilai & $80 \%$ \\
\hline
\end{tabular}




\begin{tabular}{llc} 
& Kategori & B \\
\hline \multirow{2}{*}{ Non-Lokomotor } & Nilai & $74,5 \%$ \\
& Kategori & B \\
\hline
\end{tabular}

Keterangan: Kat: Kategori; K: Kurang (33,3\%-55,5\%);

C: Cukup (55,6\%-77,8\%) B: Baik (77,9\% - 100,0\%)

Berdasarkan tabel 1 di atas dapat dijelaskan bahwa nilai kesesuaian gerak dasar Non-Lokomotor siswa sebesar 74,5\% masuk dalam kategori cukup, nilai tertinggi yang dicapai siswa sebesar $86 \%$ masuk dalam kategori baik, dan nilai terendah yang dicapai siswa sebesar $62 \%$ masuk dalam kategori cukup.

\section{Lokomotor}

Terdapat 9 jenis tes gerak dasar yang termasuk dalam kelompok gerak dasar lokomotor adalah running, jumping fro distance, jumping fro height, jumping from height, vertical jumping, horizontal jumping, hopping, skipping sliding galloping and, leaping. Dari sepuluh tes gerak dasar tersebut dapat dijelaskan nilai kesesuaian gerak lokomotor dalam tabel 2 berikut ini:

Tabel 2. Nilai Kesesuaian Gerak Lokomotor

\begin{tabular}{lcc}
\hline Gerak Dasar & & Rerata \\
\hline Running & Nilai Kategori & $94 \%$ \\
Jumping for distance & Nilai Kategori & $85 \%$ \\
Jumping fro height & Nilai Kategori & B \\
& & $89 \%$ \\
Jumping From Height & Nilai Kategori & $82 \%$ \\
Hopping & & $\mathrm{B}$ \\
Skipping & Nilai Kategori & $69 \%$ \\
Sliding & & $\mathrm{C}$ \\
Galloping & Nilai Kategori & $75 \%$ \\
& & $\mathrm{C}$ \\
Leaping & Nilai Kategori & $67 \%$ \\
\hline \multirow{2}{*}{ Lokomotor } & & $\mathrm{C}$ \\
\hline
\end{tabular}

Keterangan: Kat: Kategori; K: Kurang (33,3\%-55,5\%);

C: Cukup (55,6\%-77,8\%) B: Baik (77,9\% - 100,0\%); 
Berdasarkan tabel 2 di atas dapat dijelaskan bahwa nilai kesesuaian gerak dasar lokomotor siswa sebesar 77,4\% masuk dalam kategori baik, nilai tertinggi yang dicapai siswa sebesar $94 \%$ masuk dalam kategori baik, dan nilai terendah yang dicapai siswa sebesar 51\% masuk dalam kategori kurang.

\section{Manipulatif}

Terdapat 8 jenis tes gerak dasar yang termasuk dalam kelompok gerak dasar manipulatif adalah throwing, catching, kicking, trapping dribbling, volleying, striking dan ball rolling. Dari delapan tes gerak dasar tersebut dapat dijelaskan nilai kesesuaian gerak manipulatif yang merupakan hasil analisis dari kedelapan jenis tes dalam tabel 3 berikut ini:

Tabel 3. Nilai Kesesuaian Gerak Manipulatif

\begin{tabular}{llc}
\hline & & Rerata \\
\hline Throwing & Nilai & $91 \%$ \\
Catching & Kategori & B \\
& Nilai & $92 \%$ \\
Kicking & Kategori & B \\
& Nilai & $74 \%$ \\
Trapping & Kategori & C \\
& Nilai & $91 \%$ \\
Dribbling & Kategori & B \\
& Nilai & $92 \%$ \\
Volleying & Kategori & B \\
& Nilai & $74 \%$ \\
Striking & Kategori & C \\
& Nilai & $91 \%$ \\
Ball rolling & Kaegori & B \\
\hline \multirow{2}{*}{ Manipulatif } & Nilai & $77 \%$ \\
& Kategori & B \\
\hline
\end{tabular}

Keterangan: Kat: Kategori; K: Kurang (33,3\%-55,5\%);

C: Cukup (55,6\%-77,8\%) B: Baik (77,9\% - 100,0\%);

Berdasarkan tabel 3 di atas dapat dijelaskan bahwa nilai kesesuaian gerak dasar manipulatif siswa sebesar $85,25 \%$ masuk dalam kategori baik, nilai tertinggi yang dicapai siswa sebesar $92 \%$ masuk dalam kategori baik, dan nilai terendah yang dicapai siswa sebesar $71 \%$ masuk dalam kategori cukup. 


\section{Gerak Dasar Umum}

Gerak dasar umum adalah hasil analisis dari tiga kelompok tes gerak dasar di atas. Hasil simpulan dari analisis ketiga kelompok gerak dasar di atas menunjukkan bahwa nilai kesesuaian gerak dasar umum siswa sebesar $79 \%$ masuk dalam kategori baik.

Tabel 4. Nilai Kesesuaian Gerak Dasar Umum

\begin{tabular}{llc}
\hline \multicolumn{1}{c}{ Gerak Dasar } & & Rerata \\
\hline Non-Lokomotor & Nilai & $74,5 \%$ \\
\multirow{2}{*}{ Lokomotor } & Kategori & $\mathrm{C}$ \\
& Nilai & $77,4 \%$ \\
\multirow{2}{*}{ Manipulatif } & Kategori & $\mathrm{B}$ \\
& Nilai & $85,25 \%$ \\
& Kategori & $\mathrm{B}$ \\
\hline \multirow{2}{*}{ Gerak Dasar Umum } & Nilai & $79 \%$ \\
& Kategori & $\mathrm{B}$ \\
\hline
\end{tabular}

Keterangan: Kat: Kategori; K: Kurang (33,3\%-55,5\%);

C: Cukup (55,6\%-77,8\%) B: Baik (77,9\% - 100,0\%);

\section{DISKUSI}

Menurut Waharsono (1999:53) menyatakan, "Sejalan dengan meningkatnya ukuran tubuh dan meningkatnya kemampuan fisik, maka meningkat pulalah kemampuan geraknya". Menurut Lutan, Rusli (2001:96) bahwa, "Kemampuan motorik/gerak dasar lebih tepat disebut sebagai kapasitas dari seseorang yang berkaitan dengan pelaksanaan dan peragaan suatu keterampilan yang relatif melekat setelah masa kanak-kanak".

Sedangkan menurut Sukintaka (2004:78) bahwa, "Kemampuan motorik gerak dasar adalah kualitas hasil gerak individu dalam melakukan gerak, baik gerakan non olahraga maupun gerak dalam olahraga atau kematangan penampilan keterampilan motorik". Motor ability atau kemampuan gerak dasar pada dasarnya merupakan kemampuan yang mendasari dari gerak yang dibawa sejak lahir yang bersifat umum atau dasar yang berperan untuk melakukan gerak baik gerakan olahraga maupun non olahraga. Untuk itu, bagi siswa perlu ditanamkan kemampuan gerak dasar yang dimiliki kemudian dilatih dan dikembangkan secara maksimal sehingga siswa dapat melakukan dengan benar, bermakna, dan bermanfaat.

Perkembangan gerak dasar anak dibagi menjadi tiga periode yaitu 1) Fase perkembangan gerak dasar usia 2-7 tahun, 2) fase transisi usia 7-10 tahun 3) fase spesifikasi usia 10-13 tahun (Yudha M Saputra, 2001:14). Pada fase perkembangan gerak dasar anak mulai belajar bentuk gerak-gerak locomotor. Pada dasarnya anak sedang menjalani masa pertumbuhan, mengalami pertambahan pengalaman, mereka bergantung pada instruksi dan meniru yang lain. Pada usia ini guru mulai memberikan keterampilan persepsi motorik, keterampilan gerak dasar, keterampilan multilateral dan keterampilan terpadu. 
Pada fase transisi usia 7-10 tahun ini, anak secara individu mulai dapat menkombinasikan dan menerapkan gerak dasar yang terkait dengan penampilan dalam aktivitas jasmani. Gerakan yang silakukan berisikan unsur-unsur yang sama, seperti gerak dasar, tetapi dalam pelaksanaanya lebih akurat dan terkendali.

Pada fase spesifikasi usia 10-13 tahun ini, anak sudah dapat menentukan pilihannya akan cabang olahraga yang disukainya, secara umum mereka sudah memiliki kemampuan dalam koordinasi dan kelincahan yang jauh lebih baik. Pada fase ini mereka memilih untuk mengkhususkan pada salah satu cabang olahraga yang dianggap mampu untuk dilakukan.

Dari hasil penelitian ini dapat kita lihat bahwa dari ketiga kelompok gerkan dasar tersebut tegolong kepada baik sekali. Dengan itu ini akan mendukung terhadap tahap perkembangan selanjutnya dan juga akan memberikan sumbangan terhadap pencapaian prestasi puncak anak. Dengan demikian anak-anak ini sudah siap untuk masuk ketahap selanjutnya yaitu tahap spesialisasi seperti gambar berikut ini.

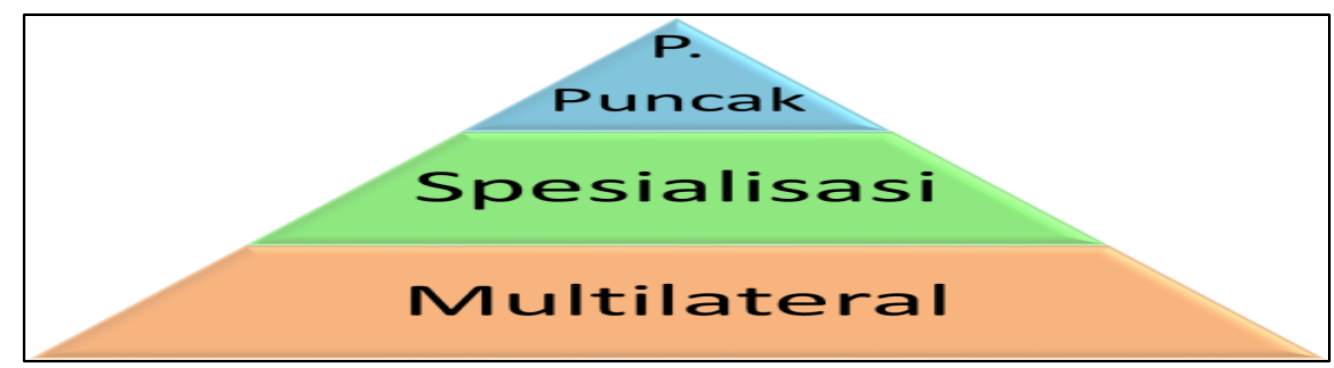

Gambar Tahapan perkembangan Motorik Terhadap Prestasi Puncak

Segala sesuatu yang kita lakukan pada domain (ranah) motorik dipengaruhi oleh emosi kita, interaksi sosial, dan perkembangan kognitif.Sejauh ini, semua perilaku pada domain afektif dan kognitif lebih kuat dipengaruhi oleh perilaku motorik. Piaget dapat mengkatagorikan perilaku kedalam 4 (empat) tahap perkembangan kognitif, yaitu:

- Sensorimotorik Lahir s/d 2 tahun

- Preoperasional 2 tahun s/d 8 tahun

- Konkret operasional 8 tahun s/d 11 tahun

- Formal operasional 11 tahun s/d 12 tahun

Teori piget ini juga sejalan dengan hasil penelitian ini bahwa anak yang berapa pada "Formal Operasional" merupakan kemampuan untuk mempertimbangkan ide-ide yang tidak didasarkan pada realita. Anak sudah mampu berpikir yang bersifat abstrak. Namun menurut piaget, banyak individu tidak pernah mencapai tahapan seperti ini, justru orang yang memiliki rata-rata skornya rendah pada tes intelegensi sangat memungkinkan tidak mencapai tahap formal operasional. Pada masa ini gerak yang dapat dikembangkan mengarah pada pencabangan olahraga. Anak sudah saatnya untuk menentukan sikap cabang olahraga apa yang akan ditekuni untuk hobi dan atau masa depannya. Pandangan kita mengenai aktivitas gerak adalah gerakan yang diciptakan melalui proses dari integrasi sensori (panca indra); hal ini termasuk semua gerakan yang dilakukan secara sukarela (tanpa paksaan), seperi aktivitas dalam mata pelajaran pendidikan jasmani. Namun, kita juga telah menyatakan bahwa tujuan dari aktivitas gerak adalah untuk meningkatkan fungsi kognitif. 
Delacato juga yakin bahwa masalah intelektual dapat ditanggulangi dengan merekapitulasi gerak awal yang diperkirakan menjadi tidak sempurna. Dia merekomendasi bahwa proses diketahui sebagai pola. Melalui pola tersebut, seorang individu mempraktekan gerak sederhana, biasanya merangkak untuk mengakomodasi kebutuhan anak dalam meningkatkan fungsi kognitifnya. Anak yang tidak mampu secara aktif merekapitulasi gerak ini secara pasif dibantu melalui gerak lain. Proses ini sering melibatkan berbagai bantuan dan sering dipelihara untuk memperpanjang waktu.

\section{KESIMPULAN}

Dari hasil tersebut dapat disimpulkan nilai kesesuaian gerak Non-Lokomotor masuk dalam kategori cukup $(74,5 \%)$, nilai kesesuaian gerak lokomotor masuk dalam kategori baik $(77,4 \%)$. nilai kesesuaian gerak manipulatif masuk dalam kategori baik $(85,25 \%)$. Dari tiga kelompok gerak dasar didapat nilai gerak dasar umum masuk dalam dalam kategori baik (79\%).

\section{DAFTAR PUSTAKA}

Gallahue, David L. dan Ozmun, John C. (1998). Understanding Motor Development: Infants, Children, Adeloscents, Adults. USA: McGraw-Hills.

Lutan, Rusli. (2001). Asas-Asas Pendidikan Jasmani. Jakarta: Depdiknas

M,Yudha Saputra. (2001). Pembelajaran Atletik di Sekoah Dasar. Jakarta: Depdiknas

Nazir, Moh. (1983). Metode Penelitian. Yogyakarta.Ghalia Indonesia.

Sukintaka. (2004). Teori Bermain untuk D2 PGSD Penjaskes. Jakarta: Depdikbud

Sumantri. (2005). Model Pengembangan keterampilan Motorik Anak Usia Dini. Jakarta: Departemen Pendidikan Nasional.

Waharsono. (1999). Materi Pelatihan Guru Pendidikan Jasmani dan Kesehatan SD/Pelatih Klub Olahraga Usia Dini. Jakarta: Depdikbud. Direktorat Pendidikan Dasar. 